\section{Overriding water table control on managed peatland greenhouse gas emissions} \\ Evans, C.D.; Peacock, M.; Baird, A.J.; Artz, R.R.E.; Burden, A.; Callaghan, N.; \\ Chapman, P.J.; Cooper, H.M.; Coyle, M.; Craig, E.; Cumming, A.; Dixon, S.; \\ Gauci, V.; Grayson, R.P.; Helfter, C,; Heppell, C.M.; Holden, J.; Jones, Davey \\ L.; Kaduk, J.; Levy, P.; Matthews, R.; McNamara, N.P.; Misselbrook, T.; Oakley, \\ S.; Page, S.E.; Rayment, Mark; Ridley, Luke; Stanley, K.M.; Williamson, J.L.; \\ Worrall, F.; Morrison, R.

\section{Nature} \\ DOI: \\ https://doi.org/10.1038/s41586-021-03523-1
}

Published: $27 / 05 / 2021$

Peer reviewed version

Cyswllt i'r cyhoeddiad / Link to publication

Dyfyniad o'r fersiwn a gyhoeddwyd / Citation for published version (APA):

Evans, C. D., Peacock, M., Baird, A. J., Artz, R. R. E., Burden, A., Callaghan, N., Chapman, P. J., Cooper, H. M., Coyle, M., Craig, E., Cumming, A., Dixon, S., Gauci, V., Grayson, R. P., Helfter, C., Heppell, C. M., Holden, J., Jones, D. L., Kaduk, J., ... Morrison, R. (2021). Overriding water table control on managed peatland greenhouse gas emissions. Nature, 593, 548-552. https://doi.org/10.1038/s41586-021-03523-1

\footnotetext{
Hawliau Cyffredinol / General rights

Copyright and moral rights for the publications made accessible in the public portal are retained by the authors and/or other copyright owners and it is a condition of accessing publications that users recognise and abide by the legal requirements associated with these rights. study or research.

- Users may download and print one copy of any publication from the public portal for the purpose of private

- You may not further distribute the material or use it for any profit-making activity or commercial gain

- You may freely distribute the URL identifying the publication in the public portal ?
} 


\section{Overriding importance of water table in the greenhouse gas balance of managed peatlands.}

Evans, C.D. ${ }^{1}$, Peacock, M. ${ }^{2}$, Baird, A.J. ${ }^{3}$, Artz, R. ${ }^{4}$, Brown, E. ${ }^{1,5}$, Burden, A. ${ }^{1}$, Callaghan, N. ${ }^{1}$, Chapman, P.J. ${ }^{3}$, Cooper, H. M. ${ }^{7}$, Coyle, M. ${ }^{4,6}$, Cumming, A. ${ }^{7}$, Dixon, S. ${ }^{8}$, Helfter, C. ${ }^{7}$, Heppell, C. ${ }^{9}$, Holden, J. ${ }^{3}$, Gauci, V. ${ }^{10}$, Grayson, R.P. ${ }^{3}$, Jones, D. ${ }^{5}$, Kaduk, J. ${ }^{11}$, Levy, ${ }^{6} .{ }^{6}$, Matthews, R. ${ }^{12}$, McNamara, N. ${ }^{13}$, Misselbrook, T. ${ }^{12}$, Oakley, S. ${ }^{13}$, Page, S. ${ }^{11}$, Rayment, M. ${ }^{5}$, Ridley, L.M. ${ }^{5}$, Stanley, K. ${ }^{9}$, Williamson, J. ${ }^{1}$, Worrall, F. ${ }^{8}$, Morrison, $R^{7}$.

1. UK Centre for Ecology and Hydrology, Bangor, LL57 2UW, UK

2. Department of Aquatic Sciences and Assessment, Swedish University of Agricultural Sciences, 756 51 Uppsala, Sweden

3. School of Geography, University of Leeds, Leeds, LS2 9JT, UK

4. The James Hutton Institute, Craigiebuckler, Aberdeen AB15 8QH, UK

5. School of Natural Sciences, Bangor University, Bangor LL57 2UW, UK

6. UK Centre for Ecology and Hydrology, Penicuik, Edinburgh, EH26 OQB, UK

7. UK Centre for Ecology and Hydrology, Wallingford, OX10 8BB, UK

8. Department of Earth Sciences, Durham University, Durham DH1 3LE, UK

9. Department of Geography, Queen Mary University of London, E1 4NS, UK

10. School of Geography, Earth and Environmental Sciences, University of Birmingham, B15 2TT, UK

11. University of Leicester, Geography, Leicester, LE1 7RH, UK

12. Rothamsted Research, North Wyke, Okehampton EX2O 2SB, UK

13. UK Centre for Ecology and Hydrology, Lancaster, LA1 4AP, UK

The global peatland carbon (C) store may exceed $1100 \mathrm{Pg}^{1,2}$, exceeding the current size of the atmospheric carbon pool. Peatlands in many parts of the world are under severe and increasing pressure from drainage-based agriculture, timber plantations and fire. Greenhouse gas (GHG)

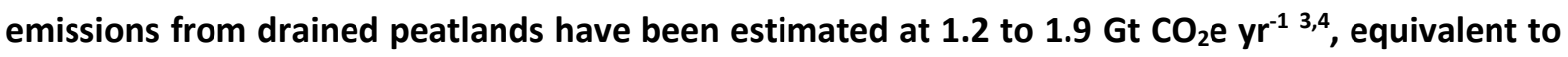
2.3-3.8\% of all anthropogenic GHG emissions ${ }^{5}$. With growing recognition of the significance of peatlands for the climate system, efforts to curb emissions through conservation of undrained peatlands and rewetting of drained systems are intensifying. Here, we describe a unique set of 16 $\mathrm{CO}_{2}$ eddy covariance datasets, and accompanying methane $\left(\mathrm{CH}_{4}\right)$ data, collected within the relatively narrow geographic and climate range of the United Kingdom, which span a broad gradient of land-use intensity from near-natural bogs and fens to intensive grassland, cropland and peat extraction. Combining these results with published data from a further 52 eddy covariance sites from across the temperate and boreal zones, we show that mean annual effective water-table depth $\left(\mathrm{WTD}_{e}\right)$ represents the overwhelmingly dominant control on $\mathrm{CO}_{2}$ fluxes, apparently overriding all other climatic, vegetation and land-management factors. We show that every $10 \mathrm{~cm}$ reduction in WTD $e$ will reduce the net warming impact of $\mathrm{CO}_{2}+\mathrm{CH}_{4}$ emissions (based on 100 year Global Warming Potentials) by at least $3 \mathrm{t} \mathrm{CO}_{2} \mathrm{e} \mathrm{ha}^{-1} \mathrm{yr}^{-1}$, until WTD $\mathrm{Ws}_{e}<30 \mathrm{~cm}$. Raising water levels above that level continues to have a net cooling impact until $\mathrm{WTD}_{e}$ is $<10 \mathrm{~cm}$. Our results suggest significant but largely unrealised potential to reduce GHG emissions from peatlands drained for agriculture, without necessarily having to halt their productive use. Assuming similar functional relationships between $\mathrm{CO}_{2}, \mathrm{CH}_{4}$ and $\mathrm{WTD}_{e}$ for tropical peatlands, we estimate that halving $\mathrm{WTD}_{e}$ in drained agricultural peatlands could reduce peatland GHG emissions by $450 \mathrm{Mt} \mathrm{CO}_{2} \mathrm{e} \mathrm{yr}^{-1}$, representing almost two thirds of the maximum feasible climate change mitigation for this area, and around $1 \%$ of global anthropogenic $\mathrm{CO}_{2}$ emissions. 
Peatlands form where high rainfall or restricted drainage cause waterlogging, restricting oxygen supply and suppressing decomposition. Peatlands mostly occur in the northern cool temperate and boreal zones ${ }^{6}$ and the humid tropics, notably Southeast Asia, Amazonia and Central Africa ${ }^{2}$. Largescale drainage of peatlands began in Europe several centuries ago, and intensified in the $20^{\text {th }}$ century following the advent of electrical pumping. The resulting aerobic organic soils release nutrients through decomposition and can provide fertile land for cropland, grassland and forestry. Out of a total European peatland area of 51 million ha, $21 \%$ has been drained for forestry, and $17 \%$ for cropland and grassland ${ }^{7}$. In Southeast Asia, an estimated $50-75 \%$ of Malaysian and Indonesian peat swamp forests have been deforested and drained since 1990, primarily for oil palm and pulpwood plantation. Drainage leads to oxidative loss of peat, land subsidence, increased fire and flood risk, and the need for energy-intensive pumped drainage ${ }^{9-12}$. As a result, crops grown on peat have among the highest production intensities (GHG emissions per crop calorie) in the world ${ }^{13}$. Nevertheless, peatland drainage and cultivation have contributed significantly to economic development in many areas, and cultivated organic soils support large populations in countries such as Indonesia. Despite the urgent need to reduce GHG emissions, it is therefore unlikely that these areas can be restored to natural wetlands in time to meet international commitments to achieve net zero GHG emissions under the Paris Agreement.

In 2014, the IPCC published new guidance on GHG emissions reporting for managed peatlands ${ }^{14}$. To develop emission factors (i.e. emissions of $\mathrm{CO}_{2}, \mathrm{CH}_{4}$, and nitrous oxide $\left(\mathrm{N}_{2} \mathrm{O}\right)$ per unit area per year) peatlands were classified by climate zone, peat type (bog versus fen) and management (e.g. cropland, grassland, forest land, re-wetted peatland). Water-table regimes were recognised as important in determining differences between categories, but were rarely taken into account explicitly. However, a range of previous studies have identified mean water-table depth (WTD) as an important influence on the emissions of all three major GHGs, with deeper water tables favouring $\mathrm{CO}_{2}$ and $\mathrm{N}_{2} \mathrm{O}$ emissions, and shallow water tables favouring $\mathrm{CH}_{4}$ emissions ${ }^{15,16}$. Nevertheless, it is widely considered that other factors such as climate, vegetation, agricultural practices such as crop residue management and fertilisation, and intrinsic peat properties, exert strong additional influences on GHG emissions ${ }^{15-18}$. Furthermore, most studies of peatland management for climate mitigation have focused on rewetting and restoration to functional wetland systems, or on high-water table agricultural use ('paludiculture'19). While these changes in management would have desirable endpoints from the perspective of re-initiating net $\mathrm{CO}_{2}$ sequestration, the reduction or loss of direct economic income resulting from these measures, as well as uncertain outcomes with regard to $\mathrm{CH}_{4}$ emissions, has precluded their large-scale implementation.

We collated $\mathrm{CO}_{2}$ flux measurements from 16 peatland eddy covariance (EC) flux towers located across the UK (Extended Data Figure 1). The sites encompass the three main temperate peatland types (fen, lowland raised bog, upland blanket bog) and a diverse range of land-use, from near-natural (including conservation-managed and re-wetted) bogs and fens to extensive and intensive grassland, arable, horticulture and peat extraction. This density of EC measurements on peat is unique globally.

Measured Net Ecosystem Exchange (net gaseous $\mathrm{CO}_{2}$ exchange, NEE) of the sites ranged from -2.5 to $+6.9 \mathrm{t} \mathrm{Cha}^{-1} \mathrm{yr}^{-1}$ (where negative values indicate net $\mathrm{CO}_{2}$ uptake). Variations were clearly associated with land-use; all net $\mathrm{CO}_{2}$ sinks were near-natural, and all drained sites were net $\mathrm{CO}_{2}$ sources, with the largest losses from cropland and intensive grassland (Extended Data Table 1). Between-year variations in NEE at near-natural/conservation-managed sites were comparatively small, despite variable weather conditions between years (see Extended Data Figure 2). At cropland sites, NEE was more variable between years, due to different rates of $\mathrm{CO}_{2}$ uptake by different crops, but after accounting for removal of $\mathrm{C}$ in harvested biomass, net ecosystem production (NEP) was again remarkably stable. 
This suggests a steady underlying rate of heterotrophic respiration and associated $\mathrm{CO}_{2}$ loss at cultivated sites, with the entire annual gross primary production (GPP) effectively lost to autotrophic respiration and biomass harvest.

For the sites with $\mathrm{CO}_{2}$ flux towers we found a strong correlation between NEP and $\mathrm{WTD}_{e}$ :

$\mathrm{NEP}=0.1341 \times \mathrm{WTD}_{e}-1.73 \quad \mathrm{R}^{2}=0.90, \mathrm{p}<0.001, \mathrm{n}=16$

(Equation 1)

No other climatic, hydrological or soil quality variable provided any additional explanatory power ( $p$ >

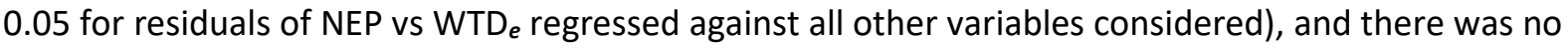
evidence of systematic deviation from the best-fit line as a function of land-use type.

Combining our EC-based NEP data with comparable values from 49 published EC studies of other temperate and boreal peatlands that also reported $\mathrm{WTD}_{e}$ (Extended Data Table 2) we obtained a similar but shallower relationship (Figure 1b):

$\mathrm{NEP}=0.0927 \times \mathrm{WTD}_{e}-1.69$

$\left(R^{2}=0.68, p<0.001, n=65\right)$

(Equation 2)

Again, we found little evidence of systematic deviation from the best-fit line as a function of land use, although there were some individual outliers. Further analysis (Supplementary Information) showed that the model was not improved (i.e. Akaike Information Criterion did not reduce) if temperature and precipitation were included as additional explanatory variables, or if a non-linear model was applied. The underlying linear relationship with $\mathrm{WTD}_{e}$ also persisted if data were grouped by land use in a linear mixed-effect model. Based on Equation 2, boreal/temperate peatlands are predicted to sequester $1.58 \mathrm{t} \mathrm{Cha}^{-1} \mathrm{yr}^{-1}$ as $\mathrm{CO}_{2}$ on average when water tables are at the peat surface, and to act as net $\mathrm{CO}_{2}$ sinks when $\mathrm{WTD}_{e}<20 \mathrm{~cm}$. Peatlands with $\mathrm{WTD}_{e}>25 \mathrm{~cm}$ were overwhelmingly net $\mathrm{CO}_{2}$ sources.

We also analysed a total of 41 measurements of annual mean $\mathrm{CH}_{4}$ flux, all from peatlands in the UK and Ireland, and made using comparable methods, spanning a range of land management, peat type and WTD $_{e}$ (see Methods, Extended Data Table 3). This dataset shows a clearly non-linear relationship between mean annual $\mathrm{CH}_{4}$ and $\mathrm{WTD}_{e}$, with maximum emissions of around $0.2 \mathrm{t} \mathrm{CH}_{4}-\mathrm{C}^{-1} \mathrm{yr}^{-1}$ when $\mathrm{WTD}_{e}$ is close to the peat surface, and predominantly near-zero emissions when $\mathrm{WTD}_{e}>30 \mathrm{~cm}$ (Figure 1c). The observations conformed to an exponential relationship:

$\mathrm{CH}_{4}=0.334 \times 0.5^{((\mathrm{WTD}+5) / 6.31)}$

(Equation 3)

(RMSE 0.044 t C ha ${ }^{-1} \mathrm{yr}^{-1}$, predicted versus observed $\mathrm{R}^{2}=0.55, \mathrm{p}<0.001, \mathrm{n}=41$ )

Again, no other measured site variable provided additional explanatory power, although previous studies have shown a significant influence of aerenchymatous vascular plant species on $\mathrm{CH}_{4}$ emissions from semi-natural peatlands, and of temperature when the water table is close to the surface ${ }^{16-17,20-}$ 21. Comparison of our results with data collected from other biogeographic regions suggests that the obtained relationship is broadly applicable (Extended Data Figure 3).

Empirical relationships with WTD for $\mathrm{CO}_{2}, \mathrm{CH}_{4}$ and their combined climate forcing impact are shown in Figure $1 \mathrm{~d}$. For $\mathrm{CO}_{2}$, the observed linear relationship suggests that a $10 \mathrm{~cm}$ rise in $\mathrm{WTD}_{e}$ within the range of observations will, on average, decrease $\mathrm{CO}_{2}$ emissions by around $3 \mathrm{t} \mathrm{CO}_{2} \mathrm{ha}^{-1} \mathrm{yr}^{-1}$. For $\mathrm{CH}_{4}$, the non-linear relationship suggests that raising water tables in deep-drained soils to $30 \mathrm{~cm}$ below the surface would have a negligible influence on $\mathrm{CH}_{4}$ emissions (maximum emission $0.3 \mathrm{t} \mathrm{CO}_{2} \mathrm{e} \mathrm{ha} \mathrm{h}^{-1} \mathrm{yr}^{-1}$ ). Raising WTD from 30 to $0 \mathrm{~cm}$ would increase $\mathrm{CH}_{4}$ emissions by approximately $7 \mathrm{t} \mathrm{CO}_{2} \mathrm{e} \mathrm{ha-1} \mathrm{yr}^{-1}$. Combining the two GHGs indicates that the change in $\mathrm{CO}_{2}$ per unit change in $\mathrm{WTD}_{e}$ exceeds the change in $\mathrm{CH}_{4}$ for all WTD ${ }_{e}>8 \mathrm{~cm}$. Consequently, any reduction in drainage depths up to that value can be 
expected to have a net beneficial impact in terms of climate forcing. Between a WTD $D_{e}$ of and $13 \mathrm{~cm}$ the cooling effect of $\mathrm{CO}_{2}$ sequestration exceeds the warming impact of $\mathrm{CH}_{4}$ emissions (based on $\mathrm{GWP}_{100}$ ) implying that peatlands in this range (which is typical of natural systems ${ }^{21}$ ) will have a small cooling impact on a 100 year time horizon. Over longer time horizons, the longer atmospheric lifetime of $\mathrm{CO}_{2}$ compared to $\mathrm{CH}_{4}$ means that this cooling impact will be stronger, and will extend to peatlands with a higher $\mathrm{WTD}_{e}{ }^{22}$. However our data do suggest that where average water levels are raised above the peat surface, the net warming effect of higher $\mathrm{CH}_{4}$ emissions is likely to exceed the cooling effect of additional $\mathrm{CO}_{2}$ sequestration over shorter time-horizons.

a)

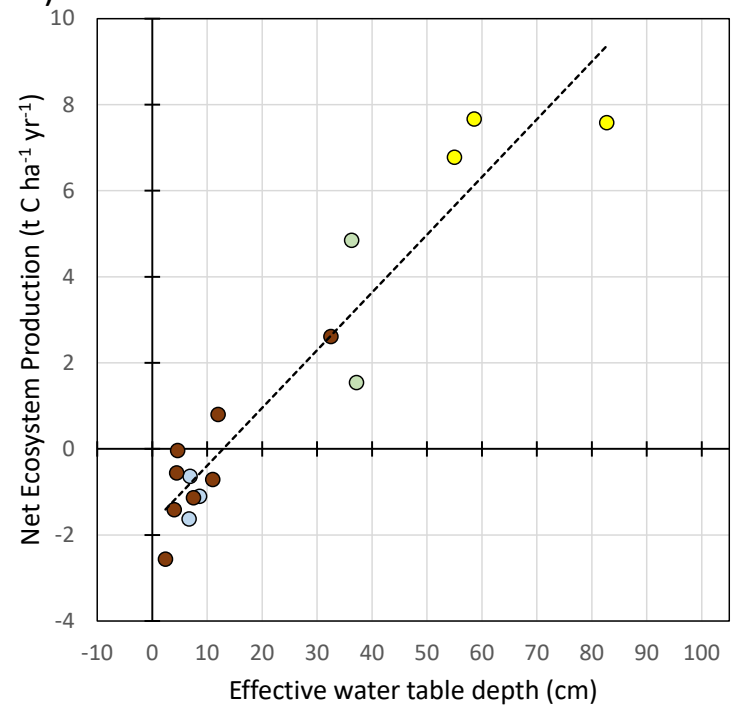

c) $\mathrm{CH}_{4}$ flux vs WTD

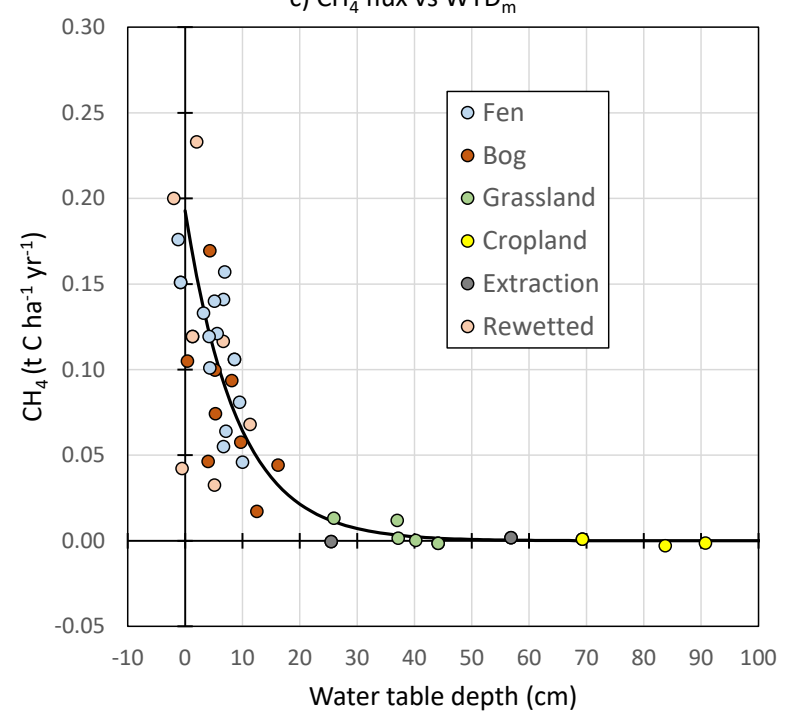

b)

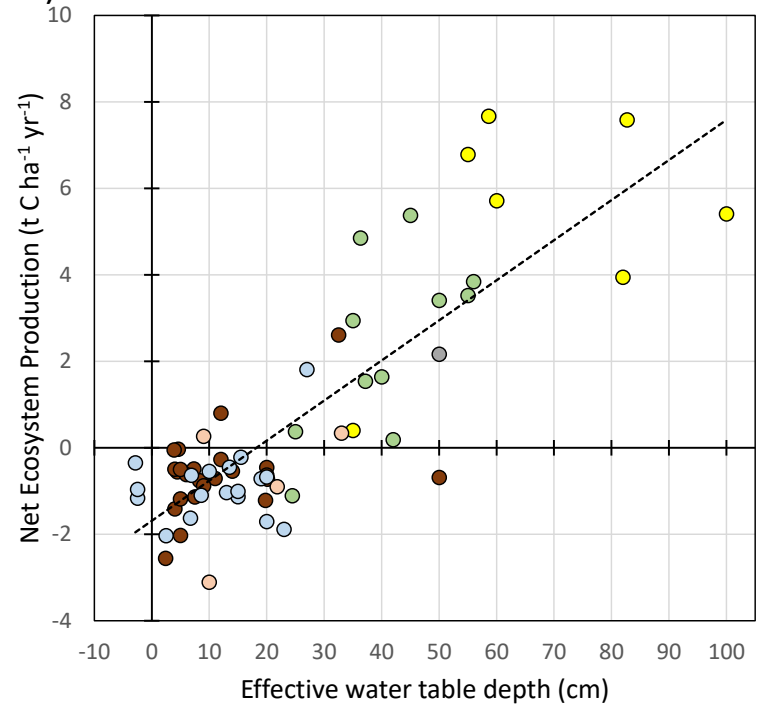

d) Net GHG $\left(\mathrm{CO}_{2}+\mathrm{CH}_{4}\right)$ balance vs WTD

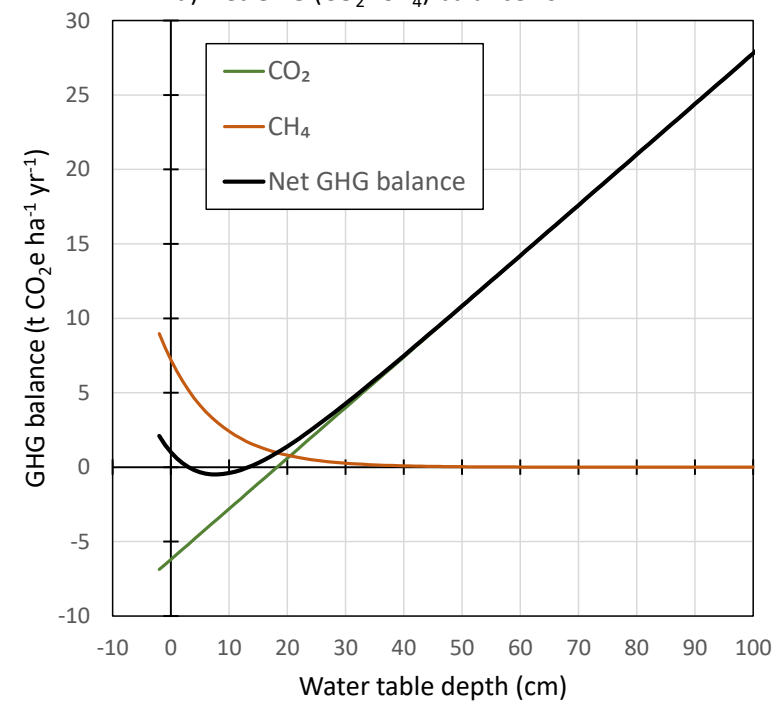

Fig 1 Annual mean flux values versus mean water table depth for: a) $\mathrm{CO}_{2}$, based on UK study sites; b) $\mathrm{CO}_{2}$ based on all published boreal/temperate EC studies in boreal and temperate; $c$ ) $\mathrm{CH}_{4}$, based on UK and Irish sites; and d) best-fit regressions from (b) and (c) converted to $t \mathrm{CO}_{2} e \mathrm{ha}^{-1} \mathrm{yr}^{-1}$ and combined to show the net climate impact of $\mathrm{CO}_{2}$ and $\mathrm{CH}_{4}$ versus water table depth (based on $G W P_{100}$ ).

In the UK, an estimated 64,000 ha of deep peat is under cropland, and 148,000 ha under intensive grassland $^{23}$. Based on typical WTD $e$ values of $90 \mathrm{~cm}$ for cropland and $60 \mathrm{~cm}$ for intensively managed grassland, we estimate that halving drainage depths across this area would reduce total $\mathrm{CO}_{2}$ emissions 
by $3.1 \mathrm{Mt} \mathrm{CO} \mathrm{yr}^{-1}$, with a negligible offsetting increase in $\mathrm{CH}_{4}$ emissions. This equates to $0.7 \%$ of the most recently reported total UK GHG emissions ${ }^{24}$.

Globally, 250,000-290,000 km² of peat are under drained cropland and grassland, and estimates of $\mathrm{CO}_{2}$ emissions from these areas, based on IPCC Tier 1 emission factors ${ }^{14,25}$, range from 680 to $1030 \mathrm{Mt}$ $\mathrm{CO}_{2} \mathrm{yr}^{-13,4,26}$. We combined the most recent area estimates ${ }^{4}$ with our observed relationship between NEP and $\mathrm{WTD}_{e}$ (Equation 2) and $\mathrm{CH}_{4}$ and $\mathrm{WTD}_{e}$ (Equation 3) to derive a revised estimate of net $\mathrm{CO}_{2}+$ $\mathrm{CH}_{4}$ emissions from these areas, assuming a global average $\mathrm{WTD}_{e}$ of $50 \mathrm{~cm}$ for grassland, and $90 \mathrm{~cm}$ for cropland (see Figure 1b, Methods). Emissions from tropical peatlands were scaled according to the ratio of emission factors for tropical and temperate/boreal cropland and grassland in the IPCC 2013 Wetlands Supplement ${ }^{14}$; see Methods). Our revised estimate of global $\mathrm{CO}_{2}$ emissions from drained organic soils under cropland and grassland of $786 \mathrm{Mt} \mathrm{CO}_{2} \mathrm{yr}^{-1}$ is within the range of previous estimates (note that $\mathrm{CH}_{4}$ emissions are negligible in this scenario). Unlike previous studies, however, our empirical relationships with drainage depth enable us to evaluate mitigation scenarios based on landmanagement change, in addition to land-use change. Reapplying Equations 2 and 3 with mean WTDs halved to $45 \mathrm{~cm}$ in cropland and $25 \mathrm{~cm}$ in grassland gives a global $\mathrm{CO}_{2}+\mathrm{CH}_{4}$ emission of $278 \mathrm{Mt} \mathrm{CO}_{2} \mathrm{e}$ $\mathrm{yr}^{-1}$, with $\mathrm{CH}_{4}$ emissions comprising $<5 \mathrm{Mt} \mathrm{CO}_{2} \mathrm{e} \mathrm{yr}^{-1}$. The net reduction of $508 \mathrm{Mt} \mathrm{CO}_{2} \mathrm{e} \mathrm{yr}^{-1}(65 \%$ of present-day emissions) under this scenario equates to $11 \%$ of total $\mathrm{CO}_{2}$ emissions from land-use (4.8 $\left.\mathrm{Gt} \mathrm{CO}_{2} \mathrm{yr}^{-15}\right)$, and $1.3 \%$ of total global anthropogenic $\mathrm{CO}_{2}$ emissions (39.6 $\mathrm{Gt} \mathrm{CO}_{2} \mathrm{yr}^{-15}$ ).

We also evaluated an 'optimal re-wetting' scenario, in which all areas currently under cropland and grassland are re-wetted to a mean $\mathrm{WTD}_{e}$ of $10 \mathrm{~cm}$ to maximise their net climate change mitigation potential (Figure 1d). This scenario would generate net $\mathrm{CO}_{2}$ uptake of $106 \mathrm{Mt} \mathrm{CO}_{2} \mathrm{yr}^{-1}$, but with an offsetting emission of $91 \mathrm{Mt} \mathrm{CO}_{2} \mathrm{yr}^{-1}$ of $\mathrm{CH}_{4}$ emissions, giving a small net $\mathrm{GHG}$ removal. Comparing the two scenarios, halving drainage depths in our 'agricultural mitigation' scenario would deliver an estimated $63 \%$ of the maximum climate mitigation achievable through optimised re-wetting.

Our analysis does not consider $\mathrm{N}_{2} \mathrm{O}$ emissions, which are believed to contribute a further $260 \mathrm{Mt} \mathrm{CO}_{2} \mathrm{e}$ $\mathrm{yr}^{-1}$ of emissions from organic soils under cropland and grassland ${ }^{26}$. However, previous analyses suggest that $\mathrm{N}_{2} \mathrm{O}$ emissions are also positively correlated with WTD ${ }^{16}$. Similarly, we did not quantify indirect emissions of $\mathrm{CO}_{2}$ via aquatic organic $\mathrm{C}$ export, but again the available evidence suggests that this flux increases following drainage ${ }^{27}$. Finally, we did not consider the potential influence of raising

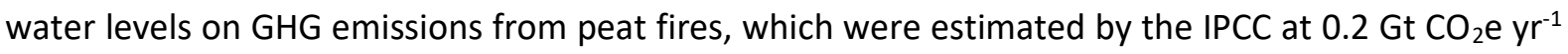
${ }^{3}$. Raising water levels in drained peatlands reduces their susceptibility to deep burns, producing potentially large additional $\mathrm{CO}_{2}$ emissions mitigation ${ }^{28}$. On this basis, we consider our estimates of the climate mitigation potential of raising water levels in agriculturally managed peatlands to be conservative. 
Table 1. Estimated total $\mathrm{CO}_{2}+\mathrm{CH}_{4}$ emissions for global drained cropland and grassland on peat, disaggregated by climate zone, for present day, 'agricultural mitigation' and 'optimal re-wetting' scenarios, based on the empirical relationships shown in Figure 1 and area data obtained from Leifeld and Menichetti ${ }^{4}$. $\mathrm{CH}_{4}$ emissions were converted to $\mathrm{CO}_{2}$ equivalents using a 100 year GWP of 28 , and negative values indicate net GHG removal. For details of calculations see Methods, and for emissions data disaggregated by gas and a comparison to previous emissions estimates see Extended Data Tables 4-5.

\begin{tabular}{|c|c|c|c|}
\hline \multirow{2}{*}{$\begin{array}{l}\text { Peat areas } \\
\text { Climate zone }\end{array}$} & \multicolumn{3}{|c|}{ Mha } \\
\hline & Cropland & Grassland & Total \\
\hline Boreal & 7.2 & 2.2 & 9.4 \\
\hline Temperate & 3.7 & 2.6 & 6.3 \\
\hline Tropical & 9.4 & 3.9 & 13.3 \\
\hline Total & 20.3 & 8.7 & 29.0 \\
\hline \multicolumn{2}{|c|}{$\mathrm{CO}_{2}+\mathrm{CH}_{4}$ emissions } & $\mathrm{Mt} \mathrm{CO} \mathrm{C} \mathrm{yr}^{-1}$ & \\
\hline \multicolumn{4}{|l|}{ Present day } \\
\hline Boreal & 174.8 & 24.2 & 199.0 \\
\hline Temperate & 90.2 & 28.0 & 118.3 \\
\hline Tropical & 395.5 & 72.8 & 468.3 \\
\hline Total & 660.5 & 125.1 & 785.6 \\
\hline \multicolumn{4}{|c|}{ "Agricultural mitigation" scenario } \\
\hline Boreal & 65.6 & 6.2 & 71.8 \\
\hline Temperate & 33.9 & 7.1 & 41.0 \\
\hline Tropical & 148.0 & 17.3 & 165.3 \\
\hline Total & 247.5 & 30.6 & 278.1 \\
\hline \multicolumn{4}{|c|}{ "Optimal re-wetting" scenario } \\
\hline Boreal & -2.9 & -0.9 & -3.8 \\
\hline Temperate & -1.5 & -2.3 & -3.8 \\
\hline Tropical & -3.8 & -3.8 & -7.6 \\
\hline Total & -8.1 & -7.0 & -15.1 \\
\hline
\end{tabular}

In the context of the Paris Agreement requirement to achieve net zero GHG emissions by 2050, there is a growing emphasis on 'negative emission' strategies to offset continuing fossil fuel emissions, such as the ' 4 per 1000 ' objective to raise soil carbon content. While such actions are clearly desirable, we argue that the urgent - and arguably more tractable - challenge of reducing existing emissions from organic soils must not be overlooked. For example, our estimated mitigation potential of $15.3 \mathrm{t} \mathrm{CO}$ $\mathrm{ha}^{-1} \mathrm{yr}^{-1}$ for halving drainage depths in cropland on organic soil compares highly favourably to estimated $\mathrm{CO}_{2}$ sequestration potential of biochar application ( 0.1 to $1 \mathrm{t} \mathrm{CO}_{2} \mathrm{ha}^{-1} \mathrm{yr}^{-129}$ ), and could thus achieve the same climate benefits within just $0.7-6.5 \%$ of the land area.

Our results present both a challenge and an opportunity. Current agricultural practices on peat rely almost entirely on crops derived from dryland ecosystems, which require drainage. Although efforts are now being made to develop wetland-adapted ('paludiculture') crops, these do not yet provide commercially viable large-scale alternatives to conventional agriculture ${ }^{30}$. Intensifying global demands for land and food mean it may be unrealistic to expect all agricultural peatlands to be rewetted and restored to their original wetland function in the near future, particularly in countries where large populations rely on peatlands for their livelihoods. Our results indicate that the development of locally appropriate mitigation measures within agricultural peatlands could deliver substantial emissions reductions. Our results do not argue against full restoration of cultivated peatlands to wetlands where 
this is achievable; our optimal re-wetting scenario effectively halts GHG emissions from these areas, and turns them into small net GHG sinks. Wetland restoration would also have unquestioned benefits for biodiversity, and (unlike partial raising of water tables under agriculture) can be considered truly sustainable. However, where societal need for drainage-based agriculture precludes full re-wetting, opportunities remain to achieve globally significant emissions reductions. In either case, water levels need to be raised rapidly to avoid further sustained radiative forcing due to peatland oxidation ${ }^{31}$, and to achieve net zero emissions on the timescale of the Paris Agreement. The development of watertolerant, economically viable crops suitable for cultivation on organic soils should therefore be a high priority for international efforts to combat climate change.

\section{Acknowledgements}

This study was supported by the UK Department for Environment, Food and Rural Affairs (Projects SP1210 and SP1218), with additional data provided from projects funded by the UK Natural Environment Research Council (SEFLOS and UKSCAPE projects), Scottish Government and Natural Resources Wales (NRW). UK flux sites were hosted by a range of organisations including G's Fresh, THE National Trust, NRW and the Balmoral Estate. We are grateful to all those responsible for collecting the published data used in the study, in particular to Maria Strack, David Holl and Hannes Keck for providing additional data and information on individual studies, and to Luca Menichetti for sharing peat mapping data.

\section{Author contributions}

CDE conceived and led the study, undertook the global upscaling, and drafted the paper. RM led the analysis of eddy covariance data. MP and SEP supported to the global flux data synthesis, and PL undertook additional statistical analysis. All co-authors contributed to data collection, analysis and interpretation, and commented on the draft manuscript.

\section{References}

1. Nichols, J.E. \& Peteet, D.M. Rapid expansion of northern peatlands and doubled estimate of carbon storage. Nat. Geosci. 12, 917-921 (2019).

2. Dargie, G.C. et al. Age, extent and carbon storage of the central Congo Basin peatland complex. Nature 542, 86 (2017).

3. Smith P. et al. Agriculture, Forestry and Other Land Use (AFOLU). In: Climate Change 2014: Mitigation of Climate Change. Contribution of Working Group III to the Fifth Assessment Report of the Intergovernmental Panel on Climate Change (2014).

4. Leifeld, J. \& Menichetti, L. The underappreciated potential of peatlands in global climate change mitigation strategies. Nat. Comms. 9, 1071 (2018).

5. Le Quéré, C. et al. Global Carbon Budget 2017. Earth Syst. Sci. Data 10, 405-448 (2018).

6. Yu, Z.C. Northern peatland carbon stocks and dynamics: a review. Biogeosci. 9, 4071-4085 (2012).

7. Byrne, K.A. EU Peatlands: Current carbon stocks and trace gas fluxes. CarboEurope-GHG, concerted action synthesis of the European greenhouse gas budget, Department of Forest Science and Environment, Viterbo, Italy (2004)

8. Wijedasa, L. et al. Carbon emissions from South-East Asian peatlands will increase despite emission-reduction schemes. Global Change Biol. 24, 5498-4613 (2018).

9. Hutchinson, J.N. Record of peat wastage in the East-Anglian fenlands at Holme Post, 1848-1978 AD. J. Ecol. 68, 229-249 (1980).

10. Hooijer, A. et al. Subsidence and carbon loss in drained tropical peatlands. Biogeosciences 9 , 1053-1071 (2012) 
11. Turetsky, M. R. et al. Global vulnerability of peatlands to fire and carbon loss. Nature Geosci. 8, 11-14 (2015).

12. Evans, C.D. et al. Rates and spatial variability of peat subsidence in Acacia plantation and forest landscapes in Sumatra, Indonesia. Geoderma 338, 410-421 (2019)

13. Carlson, K.M. et al. Greenhouse gas emissions intensity of global croplands. Nat. Climate Change 7, 62-68 (2016).

14. IPCC. 2013 Supplement to the 2006 IPCC Guidelines for National Greenhouse Gas Inventories: Wetlands. IPCC Task Force on National Greenhouse Gas Inventories (2014).

15. Tiemeyer, B. et al. High emissions of greenhouse gases from grasslands on peat and other organic soils. Glob. Change Biol. 22, 4134-4149 (2016).

16. Couwenberg, J. et al. Assessing greenhouse gas emissions from peatlands using vegetation as a proxy. Hydrobiologia 674, 67-89 (2011).

17. Dias, A.T.C. et al. Plant species composition can be used as a proxy to predict methane emissions in peatland ecosystems after landuse changes. Ecosystems 13, 526-38 (2014).

18. Pohl, $M$. et al. Dynamic $C$ and $N$ stocks - key factors controlling the $C$ gas exchange of maize in heterogeneous peatland. Biogeosciences 12, 2737-2752 (2015).

19. Joosten, H., Tapio-Biström, M-L. \& Tol, S. Peatlands - guidance for climate change mitigation, conservation, rehabilitation and sustainable use. Mitigation of Climate Change in Agriculture Series 5, Food and Agriculture Organisation of the United Nations (2012).

20. Cooper, M. et al. Infilled ditches are hotspots of landscape methane flux following peatland restoration. Ecosystems 17, 1227-1241 (2014).

21. Turetsky, M.R. et al. A synthesis of methane emissions from 71 northern, temperate, and subtropical wetlands. Global Change Biol. 20, 2183-2197 (2014).

22. Frolking, S., Roulet, N., Fuglestvedt, J. How northern peatlands influence the Earth's radiative budget: Sustained methane emission versus sustained carbon sequestration. J. Geophys. Res. 111, G01008 (2006).

23. Evans, C. et al. Implementation of an emission inventory for UK peatlands. Report to the Department for Business, Energy and Industrial Strategy, Centre for Ecology and Hydrology (2017).

24. Brown, P. et al. UK Greenhouse Gas Inventory, 1990 to 2017. Annual Report for Submission under the Framework Convention on Climate Change, Department for Business, Energy \& Industrial Strategy (2019).

25. Intergovernmental Panel on Climate Change. 2006 IPCC Guidelines for National Greenhouse Gas Inventories (2006).

26. Food and Agriculture Organisation of the United Nations. FAOSTAT. www.fao.org/faostat/en/\#data.

27. Evans, C.D., Renou-Wilson, F. \& Strack, M (2016). The role of waterborne carbon in the greenhouse gas balance of drained and re-wetted peatlands. Aquat. Sci. 78, 573-590.

28. Granath, G., Moore, P.A., Lukenbach, M.C. \& Waddington, J.M. Mitigating wildfire carbon loss in managed northern peatlands through restoration. Sci. Rep. 6, 28498 (2016)

29. Paustian, K. et al. Climate-smart soils. Nature 532, 49-57 (2016)

30. Ferré, M. Sustainable management of cultivated peatlands in Switzerland: Insights, challenges, and opportunities. Land Use Policy 87, 104019 (2019).

31. Günther, A. et al. Prompt rewetting of drained peatlands reduces climate warming despite methane emissions. Nature Comms 11, 1644 (2020).

\section{METHODS}

\section{$\mathrm{UK} \mathrm{CO}_{2}$ flux data collection}

We included new $\mathrm{CO}_{2}$ flux data collected using the eddy covariance (EC) method at thirteen peatland sites in the UK, comprising four blanket bogs, one raised bog, three conservation-managed fens, two 
grasslands and three croplands ${ }^{31-34}$ (Extended Data Figure 1, Extended Data Table 1). The dataset was augmented with previously published results from two further blanket bog sites in Northern Scotland ${ }^{35}$ and one in Ireland ${ }^{36}$. This density of flux towers on peat within one region is believed to be unique. Peat depth at the measurement sites ranged from $0.4 \mathrm{~m}$ to $6 \mathrm{~m}$.

All flux tower sites had at least one full year of measurements, up to a maximum of six years. All sites had fast response gas analysers which measure the atmospheric mass density of $\mathrm{CO}_{2}$ and water vapour. Open-path analysers (either LI-7500 or LI-7500A, LI-COR Biosciences, Lincoln, Nebraska, US) were deployed across the majority of sites. most sites), An LI-7200 enclosed-path analyser was used at the Cairngorms site, and a closed path analyser (LI-7000) was deployed at Auchencorth Moss. Simultaneous measurements of the three vector components of atmospheric turbulence were made using either a Campbell Scientific CSAT3 (Logan, Utah, USA) or a Gill Instruments Ltd. (Lymington, UK) sonic anemometer (model: Solent R3, HS, WindMaster or WindMaster PRO). Fast (20 Hz) data were logged on a CR3000 Measurement and Control System (Campbell Scientific Inc. Logan, Utah, USA) or a LI7550 data logger.

All EC data were processed using EddyPRO ${ }^{\circledR}$ flux calculation software (LI-COR Biosciences, Lincoln, Nebraska, USA) following widely adopted flux calculation and correction protocols to ensure consistency across sites. All data were quality checked using standardised tests for outlier removal ${ }^{37}$, technical quality ${ }^{38}$ and spatial representativeness ${ }^{39}$. Measured net ecosystem $\mathrm{CO}_{2}$ exchange (NEE) was gap-filled and partitioned into estimates of gross primary production (GPP) and total ecosystem respiration (ER) using standardised methods of the global Fluxnet community ${ }^{40,41}$. Uncertainties in daily and annual $\mathrm{CO}_{2}$ fluxes were calculated for the EC data based on random sampling errors ${ }^{37}$ and uncertainties introduced by data gap-filling ${ }^{40,41}$. Random uncertainties for measured $\mathrm{CO}_{2}$ flux densities were estimated as standard deviations based on the method of Finkelstein \& Simms ${ }^{42}$. Uncertainty introduced by data gap-filling was estimated as the standard deviation of the values that were averaged to fill data gaps ${ }^{41}$. Uncertainties in time integrated $\mathrm{CO}_{2}$ fluxes were calculated as the square root sum of square of the thirty-minute uncertainty estimates for measured and gap-filled fluxes ${ }^{32}$. Energy balance closure (a check of the performance of an EC system at a measurement site) ranged from 60 to $96 \%$ (mean slope $=0.8 \pm 0.13, n=11$ sites) of the independently measured available energy at sites where all terms of the surface energy balance were monitored.

Water-table depths were measured manually at all sites using PVC dipwells using a dip-meter, and then corrected to the distance from the peat surface (data were recorded as positive distance below the surface, with negative values indicating ponding above the peat surface). At most sites a calibrated water-level sensor (pressure transducer) and integrated logger was also used to record water table depth in at least one dipwell, at a minimum one-hour frequency. Peat depth was measured at multiple locations around each site by probing. For each site, we calculated 'effective' mean water table depth as whichever was the smallest out of the mean annual measured water table depth, and measured peat depth. In other words, at sites where the water table fell below the base of the peat, we considered that the depth of mean provided the most appropriate estimate of the depth of organic matter exposed to aerobic decomposition. For sites under agricultural management, $\mathrm{C}$ removals in harvested biomass were quantified through a combination of direct (dry weight) measurements of harvested biomass supported by information from farm managers on crop yields, and literature data or information from comparable sites where necessary. For the purposes of deriving a site $\mathrm{CO}_{2}$ balance, we assumed that all harvested biomass would be converted to $\mathrm{CO}_{2}$ within the same year.

\section{Global $\mathrm{CO}_{2}$ flux data collation}

To place our results into a broader context, we collated a large dataset of published $\mathrm{CO}_{2}$ balance data obtained from eddy covariance (EC) measurements on peatlands in the temperate and boreal climate 
zones $^{43-92}$ (Extended Data Figure 4). We restricted the analysis to EC studies, on the basis that these provide the best and most methodologically consistent measurements of $\mathrm{CO}_{2}$ balance, and should be relatively comparable. Sites were included if they provided sufficient data to derive a direct (gaseous) annual $\mathrm{CO}_{2}$ balance, and an estimate of mean annual water-table depth (WTD). At natural sites with more complex (e.g. hummock-hollow) topography we expressed WTD relative to the mean surface elevation rather than (as in some studies) the hummock tops. As for own study sites, we defined effective WTD $\left(W_{T} D_{e}\right)$ as whichever was the smallest of WTD and the reported peat depth. For agriculturally managed sites, we only included studies that provided sufficient information on estimated $C$ offtake in harvested biomass. Plantation forest sites were not included, because no studies reported $\mathrm{C}$ balance over a full forest rotation (and thus are not in steady state with regard to biomass uptake and removal). However, naturally treed peatlands were considered to be at steady state (with regard to biomass $\mathrm{C}$ ) and were therefore included. For eight boreal/subarctic sites which reported fluxes for the growing season only, we assigned winter fluxes using the authors' own estimates where provided ( 3 sites), and for the remaining sites we applied an average winter flux estimate of $1.5 \mathrm{~g} \mathrm{C} \mathrm{m}^{-2}$ month $^{-1}$ based on the mean of measured values from five comparable sites where winter EC data were collected.

We excluded a small number of sites where average water-table depths were more than $5 \mathrm{~cm}$ above the ground surface as a result of excessive re-wetting or rice cultivation ${ }^{82}$. Sites that had been subject to recent land-use change (e.g. forest removal ${ }^{35}$ ) or fire ${ }^{84}$ were also omitted, due to the contribution of decaying biomass to $\mathrm{CO}_{2}$ emissions ${ }^{93}$. In total, we extracted data from 49 published temperate/boreal EC studies (Extended Data Table 2) giving a total dataset of 65 eddy covariance studies. We also obtained data from three published tropical peatland flux tower studies ${ }^{94,95}$, which are insufficient to support a separate analysis, but included in Extended Data Table 2 for reference.

\section{$\mathrm{CH}_{4}$ flux data collection and collation}

We analysed new $\mathrm{CH}_{4}$ flux data, measured using static chambers, from 31 UK locations within 11 discrete peatland areas of England and Wales, most of which also had at least one flux tower for $\mathrm{CO}_{2}$ measurement as described above. Additional data spanning a range of vegetation and WTD are two of the sites were provided by Ref 96 . Multiple measurements locations within individual sites were selected in order to capture local variations in vegetation, management and water table depth. As for the $\mathrm{CO}_{2}$ flux data analysis, re-wetted sites that were frequently or continuously inundated during the study period were excluded from the analysis.

Methane fluxes were measured at multiple (usually six) locations, following standard static chamber methods ${ }^{97,98}$. Chambers comprised transparent $3 \mathrm{~mm}$ thick acrylic sheet with a height of $50 \mathrm{~cm}$, and a base of $60 \times 60 \mathrm{~cm}$. During measurements these were attached to 20-30 cm deep collars inserted 10 $\mathrm{cm}$ into the soil, which were left permanently in place wherever possible to minimise disturbance (at arable sites it was necessary to remove and re-install the collars between measurements to avoid them being damaged during routine farming activities). For taller vegetation, stackable extensions were used to increase chamber height. Chambers incorporated fans to increase air circulation within the chamber, and a double gas bag arrangement to allow air pressure equilibration.

At the majority of sites, manual chamber measurements were made 12-16 times per year (with a higher frequency during the growing season and a reduced frequency during winter), for the duration of the study at each site (typically three years, minimum one year). Measurements were mostly made between 10:00 and 16:00. On each measurement occasion, sequential chamber tests lasting 3-5 minutes each were made using dark chambers. At most sites a Los Gatos Ultra-Portable Greenhouse Gas Analyser (Model 915-0011; Los Gatos Research, Mountain View, California) was used to measure within-chamber $\mathrm{CH}_{4}$ concentrations, with a 5 second measurement frequency. At one site where a Los Gatos analyser was unavailable, $\mathrm{CH}_{4}$ fluxes were measured by collecting five sequential chamber gas 
samples over a 21 minute period for analysis using gas chromatography. Finally, at one set of grassland sites at Cors Fochno, $\mathrm{CH}_{4}$ fluxes were measured using a set of 14 LI-COR LI-8100A autochambers connected to a Los Gatos analyser via a LI-COR LI-8150 multiplexer unit. These smaller chambers were installed over $21 \mathrm{~cm}$ circular collars (other specifications as above) along a $30 \mathrm{~m}$ transect at each site, and flux measurements were made at 1.5 hour intervals during monthly deployments of up to 48 hours. At all sites, air pressure and soil temperature were measured at the start of each chamber test, and chamber headspace temperature and humidity were logged every 10 seconds.

Sequential $\mathrm{CH}_{4}$ concentration data from each chamber test were converted to fluxes per unit ground surface area by linear regression against time using a standardised method, taking account of the chamber dimensions. Individual datasets were analysed visually to identify periods of linear change in concentration over time, and to exclude anomalous readings (for example associated with $\mathrm{CH}_{4}$ ebullition events) based on pre-defined protocols. At the manually sampled chamber site it was generally not possible to derive reliable empirical models of instantaneous flux versus measured meteorological or environmental variables, and here we estimated annual means from the mean of all measurements taken within each calendar month ${ }^{99}$. At the autochamber sites the higher temporal resolution of data allowed us to model annual $\mathrm{CH}_{4}$ fluxes based on a non-linear regression versus soil temperature. Note that the flux measurement method is likely to have captured steady ebullition fluxes ${ }^{100}$ but may have omitted some episodic ebullition at very wet sites ${ }^{101}$. For full details of static chamber design, operation and data processing, see Evans et al. ${ }^{31}$.

We augmented our primary dataset of $\mathrm{CH}_{4}$ flux measurements with published values obtained from similar locations within the UK and Ireland ${ }^{93,101-108}$, using comparable measurement methods (static chamber measurements using fast $\mathrm{CH}_{4}$ analysers or analysis of vial samples on a gas chromatograph). We took this approach with the aim of elucidating the influence of key land-management drivers (notably drainage depth) while minimising the influence of intrinsic factors linked to climate, peat type and inter-regional differences in vegetation, as well as potential methodological differences. The full dataset is shown in Extended Data Table 3. We also evaluated the wider applicability of the relationships obtained by comparison to three independent data syntheses from the UK ${ }^{109}$, continental Europe ${ }^{16}$, and a set of North American and Fennoscandian sites ${ }^{21}$ (Extended Data Figure 3)

\section{Flux data analysis}

We assessed the relationship between NEP and WTD $\mathrm{W}_{e}$ using simple linear regression, incorporating all site types. We also tested for non-linearity using polynomial regression, and for the possible effects of site type and additional climate variables using a linear mixed effect model; for the results of this extended data analysis see Supplementary Information. For $\mathrm{CH}_{4}$, which clearly showed a non-linear relationship with $\mathrm{WTD}_{e}$, an exponential 'half-life' model was fitted with the form:

$\mathrm{FCH}_{4}=\mathrm{A} \times 0.5^{\frac{W T D e+5}{B}}$

(Equation 4)

Where $\mathrm{FCH}_{4}$ is the mean measured flux expressed in $\mathrm{t} \mathrm{Cha}^{-1} \mathrm{yr}^{-1}, \mathrm{WTD}_{e}$ is mean effective water table depth in $\mathrm{cm}\left(5 \mathrm{~cm}\right.$ was added to all values, so that sites with WTD $_{\mathrm{e}}$ slightly above the surface that were included in the analysis had positive values in the equation), and $A$ and $B$ are fitted constants: $A$ is the value of $\mathrm{FCH}_{4}$ when WTD is $5 \mathrm{~cm}$ above the peat surface, and $\mathrm{B}$ is the change in $\mathrm{WTD}_{e}$ over which $F \mathrm{FH}_{4}$ halves in magnitude. Equation 4 was fitted to the dataset by sequentially iterating $B$ to maximise the $\mathrm{R}^{2}$ of a regression through the origin between predicted and observed $\mathrm{FCH}_{4}$, and then adjusting $\mathrm{A}$ until a gradient of 1 on this relationship was obtained.

\section{Estimates of UK and global peat emissions and mitigation potential}


We obtained global estimates of grassland and cropland extent on drained organic soils, and associated GHG emissions, from two sources: the FAOSTAT website of the Food and Agriculture Organisation of the United Nations ${ }^{25}$, and the analysis of Leifeld and Menichetti ${ }^{4}$. The estimates were derived using different data sources, aggregated differently by climate zone, and based on the IPCC's $2006^{24}$ and $2013^{14}$ emissions factors for drained organic soils respectively. FAOSTAT data were also used in the IPCC $5^{\text {th }}$ assessment report (AR5) ${ }^{3}$. For our analysis we took the cropland and grassland area estimates by climate zone provided by Leifeld and Menichetti ${ }^{4}$, and derived estimates of total $\mathrm{CO}_{2}$ and $\mathrm{CH}_{4}$ emissions based on Equations 2 and 3, for three illustrative water table scenarios. For the 'present day' scenario we assigned mean $\mathrm{WTD}_{e}$ values of $90 \mathrm{~cm}$ for cropland and $50 \mathrm{~cm}$ for grassland, based on the observations for these land-use classes in our collated flux dataset (Supplementary Tables 1 and 2). For boreal and temperate regions we applied Equation 3 directly.

For tropical peatlands, direct application of Equation 3 would likely produce an underestimate of emissions, because respiration rates for an equivalent drainage depth are expected to be faster in the higher temperatures experienced by tropical peatlands ${ }^{14}$. While there are currently insufficient EC data to derive an empirical NEP-WTD relationship for tropical peatlands, long-term measurements of peat subsidence suggest that peat loss in drained tropical peatlands is linearly related to WTD, as it is in high-latitude peatlands, but with a steeper response ${ }^{10,12}$. On this basis, we derived indicative estimates of $\mathrm{CO}_{2}$ emissions from agriculturally drained tropical peatlands by applying Equation 3 as above, and then scaling up the resulting $\mathrm{CO}_{2}$ flux based on the ratio of Tier $1 \mathrm{EFs}$ for tropical and boreal/temperate croplands and grasslands according to the most recent values presented in the IPCC Wetlands Supplement ${ }^{14}$. The resulting scale factors were 1.77 and 1.68 for cropland and grassland respectively. We applied the same $W_{T D}$ values to tropical cropland and grassland as for high-latitude peatlands.

For $\mathrm{CH}_{4}$, we applied the relationship between emissions and $\mathrm{WTD}_{e}$ derived from our dataset (Equation 3), after checking for consistency with data from previous regional and global syntheses (Extended Data Figure 4). To compare the relative warming impact of $\mathrm{CH}_{4}$ and $\mathrm{CO}_{2}$ emissions, we used the most recent IPCC AR5 100 year Global Warming Potential (GWP) of 28, which excludes carbon-climate feedbacks.

Finally, to calculate the emissions mitigation potential of raising water levels in agriculturally managed peatlands, we re-applied Equations 3 and 4 to the FAOSTAT dataset, with WTD $e$ halved to $45 \mathrm{~cm}$ under cropland and $25 \mathrm{~cm}$ under grassland. This adjustment is arbitrary, and intended to illustrate the magnitude of emissions mitigation that could be attained if economically viable methods of managing cropland and grassland systems at high water levels could be implemented.

\section{Additional References}

32. Evans, C.D. et al. Lowland peatland systems in England and Wales - evaluating greenhouse gas fluxes and carbon balances. Final report to Defra on Project SP1210, Centre for Ecology and Hydrology, Bangor (2016).

33. Levy, P. E. \& Gray, A. Greenhouse gas balance of a semi-natural peatbog in northern Scotland. Environ. Res. Lett. 10, 94019 (2015).

34. Helfter, C. et al. Drivers of long-term variability in $\mathrm{CO}_{2}$ net ecosystem exchange in a temperate peatland. Biogeosciences, 12, 1799-1811 (2015).

35. Peacock, M. et al. The full carbon balance of a rewetted cropland fen and a conservationmanaged fen. Agric. Ecosys. Environ. 269, 1-12 (2019). 
36. Hambley, G. et al. Net ecosystem exchange from two formerly afforested peatlands undergoing restoration in the Flow Country of northern Scotland. Mires \& Peat 23, 05 (2019).

37. McVeigh, P., Sottocornola, M., Foley, N., Leahy, P., Keily, G. Meteorological and functional response partitioning to explain interannual variability of $\mathrm{CO}_{2}$ exchange at an Irish Atlantic blanket bog. Agric. Forest Meteorol. 194, 8-19 (2014).

38. Papale, D. et al. Towards a standardized processing of Net Ecosystem Exchange measured with eddy covariance technique: algorithms and uncertainty estimation. Biogeosciences 3, 571-583 (2006).

39. Foken, T. et al. Post-Field Data Quality Control. in Handbook of Micrometeorology 181-208 (Kluwer Academic Publishers, 2004). doi:10.1007/1-4020-2265-4_9

40. Kormann, R. \& Meixner, F. X. An analytical footprint model for non-neutral stratification. Boundary-Layer Meteorol. 99, 207-224 (2001).

41. Reichstein, M. et al. On the separation of net ecosystem exchange into assimilation and ecosystem respiration: Review and improved algorithm. Glob. Chang. Biol. 11, 1424-1439 (2005).

42. Reichstein, M., Moffat, Maria, A., Wutzler, T. \& Sickel, K. REddyProc: Data processing and plotting utilities of (half-)hourly eddy-covariance measurements. (2016).

43. Finkelstein, P. L. \& Sims, P. F. Sampling error in eddy correlation flux measurments. J. Geophys. Res. 106, 3503-3509 (2001).

44. Wang, M. et al. Can abandoned peatland pasture sequestrate more carbon dioxide from the atmosphere than an adjacent pristine bog in Newfoundland, Canada? Agric. Forest Meteorol. 248, 91-108 (2018).

45. Roulet, N.T. et al. Contemporary carbon balance and late Holocene carbon accumulation in a northern peatland. Global Change Biol., 13, 397-411 (2007).

46. Nugent, K.A., Strachan, I.B., Strack, M., Roulet, N.T., \& Rochefort, L., Multi-year net ecosystem carbon balance of a restored peatland reveals a return to carbon sink. Global Change Biol. 24, 5751-5768 (2018).

47. Lund, M., Lindroth, A., Christensen, T.R. \& Ström, L. Annual $\mathrm{CO}_{2}$ balance of a temperate bog. Tellus B: Chem. Phys. Meteorol. 59, 804-811 (2007)

48. Ratcliffe, J.L., Campbell, D.I., Clarkson, B.R., Wall, A.M. \& Schipper, L.A. Water table fluctuations control $\mathrm{CO}_{2}$ exchange in wet and dry bogs through different mechanisms. Sci. Total Environ. 655, 1037-1046 (2019).

49. Lee, S-C et al. Annual greenhouse gas budget for a bog ecosystem undergoing restoration by rewetting. Biogeosciences 14, 2799-2814 (2017).

50. D' Acunha, B., Morillas, L., Black, T.A., Christen, A. \& Johnson, M.S. Net ecosystem carbon balance of a peat bog undergoing restoration: integrating $\mathrm{CO}_{2}$ and $\mathrm{CH}_{4}$ fluxes from eddy covariance and aquatic evasion with DOC drainage fluxes. J. Geophys. Res. Biogeosci. 124, 884901 (2019).

51. Strachan, I.B., Pelletier, L. \& Bonneville, M.C. Inter-annual variability in water table depth controls net ecosystem carbon dioxide exchange in a boreal bog. Biogeochemistry 127, 99-111 (2016).

52. Humphreys, E.R., Charron, C., Brown, M. \& Jones, R. Two bogs in the Canadian Hudson Bay Lowlands and a temperate bog reveal similar annual net ecosystem exchange of $\mathrm{CO}_{2}$. Arctic, Antarctic Alpine Res. 46, 103-113 (2014).

53. Holl, D., Pancotto, V., Heger, A., Camargo, S.J. \& Kutzbach, L. Cushion bogs are stronger carbon dioxide net sinks than moss-dominated bogs as revealed by eddy covariance measurements on Tierra del Fuego, Argentina. Biogeosciences 16, 3397-3423 (2019).

54. Hao, Y.B. et al. Predominance of precipitation and temperature controls on ecosystem $\mathrm{CO}_{2}$ exchange in Zoige alpine wetlands of Southwest China. Wetlands 31, 413-422 (2011).

55. Helbig, M. et al. Direct and indirect climate change effects on carbon dioxide fluxes in a thawing boreal forest-wetland landscape. Global Change Biol. 23, 3231-3248 (2017). 
56. Helbig, M., Quinton, W.L. \& Sonnentag, O. Warmer spring conditions increase annual methane emissions from a boreal peat landscape with sporadic permafrost. Environ. Res. Lett. 12, 115009 (2017).

57. Hommeltenberg, J. et al. Ecosystem scale methane fluxes in a natural temperate bog-pine forest in southern Germany. Agric. Forest Meteor., 198, 273-284 (2014).

58. Drollinger, S., Maier, A. \& Glatzel, S., Interannual and seasonal variability in carbon dioxide and methane fluxes of a pine peat bog in the Eastern Alps, Austria. Agric. Forest Meteor. 275, 69-78 (2019).

59. Olefeldt, D. et al. Net carbon accumulation of a high-latitude permafrost palsa mire similar to permafrost-free peatlands. Geophys. Res. Lett. 39, L03501 (2012).

60. Nilsson, M. et al. Contemporary carbon accumulation in a boreal oligotrophic minerogenic mire-a significant sink after accounting for all C-fluxes. Global Change Biol. 14, 2317-2332 (2008).

61. Pullens, J.W.M., Sottocornola, M., Kiely, G., Toscano, P., \& Gianelle, D. Carbon fluxes of an alpine peatland in Northern Italy. Agric. Forest Meteor. 220, 69-82 (2016).

62. Olson, D.M., Griffis, T.J., Noormets, A., Kolka, R. and Chen, J. Interannual, seasonal, and retrospective analysis of the methane and carbon dioxide budgets of a temperate peatland. $J$. Geophys. Res. Biogeosciences, 118, 226-238 (2013).

63. Liu, L. et al. Contemporary, modern and ancient carbon fluxes in the Zoige peatlands on the Qinghai-Tibetan Plateau. Geoderma, 352, 138-149 (2019).

64. Yu, X., Song, C., Sun, L., Wang, X. \& Tan, W. Towards an improved utilization of eddy covariance data: Growing season $\mathrm{CO}_{2}$ exchange from a permafrost peatland in the Great Hing'an Mountains, Northeast China. Ecol. Ind. 115, 106427 (2020).

65. Miao, Y. et al. Growing season methane emission from a boreal peatland in the continuous permafrost zone of Northeast China: effects of active layer depth and vegetation. Biogeosciences, 9, 4455-4464 (2012).

66. Sonnentag, O., Van Der Kamp, G., Barr, A.G. \& Chen, J.M. On the relationship between water table depth and water vapor and carbon dioxide fluxes in a minerotrophic fen. Global Change Biol. 16,1762-1776 (2010)

67. Aurela, M., Lohila, A., Tuovinen, J.P., Hatakka, J., Riutta, T. \& Laurila, T. Carbon dioxide exchange on a northern boreal fen. Boreal Env. Res. 14, 699-710 (2009).

68. Aurela, M. et al. Carbon dioxide and energy flux measurements in four northern-boreal ecosystems at Pallas. Boreal Env. Res. 20, 455-473 (2015).

69. Aurela, M. et al. $\mathrm{CO}_{2}$ exchange of a sedge fen in southern Finland-the impact of a drought period. Tellus $B, 59,826-837$ (2007).

70. Aurela, M., Laurila, T. \& Tuovinen, J.P. The timing of snow melt controls the annual $\mathrm{CO} 2$ balance in a subarctic fen. Geophys. Res. Lett. 31, L16119 (2004).

71. Schulze, E.D., Prokuschkin, A., Arneth, A., Knorre, N. \& Vaganov, E.A., Net ecosystem productivity and peat accumulation in a Siberian Aapa mire. Tellus B 54. 531-536 (2002).

72. Friborg, T., Soegaard, H., Christensen, T.R., Lloyd, C.R. \& Panikov, N.S., Siberian wetlands: Where a sink is a source. Geophys. Res. Lett. 30, 2129 (2003).

73. Flanagan, L.B. \& Syed, K.H. Stimulation of both photosynthesis and respiration in response to warmer and drier conditions in a boreal peatland ecosystem. Global Change Biol. 17, 2271-2287 (2011).

74. Adkinson, A.C., Syed, K.H. \& Flanagan, L.B. Contrasting responses of growing season ecosystem $\mathrm{CO}_{2}$ exchange to variation in temperature and water table depth in two peatlands in northern Alberta, Canada. J. Geophys. Res.: Biogeosciences, 116, G01004 (2011).

75. Joiner, D.W., Lafleur, P.M., McCaughey, J.H. \& Bartlett, P.A. Interannual variability in carbon dioxide exchanges at a boreal wetland in the BOREAS northern study area. J. Geophys. Res.: Atmos, 104, 27663-27672 (1999). 
76. Bubier, J., Moore, T., Savage, K. \& Crill, P. A comparison of methane flux in a boreal landscape between a dry and a wet year. Global Biogeochem. Cycl. 19, GB1023 (2005).

77. Aslan-Sungur, G., Lee, X., Evrendilek, F. \& Karakaya, N. Large interannual variability in net ecosystem carbon dioxide exchange of a disturbed temperate peatland. Sci. Total Environ. 554, 192-202 (2016).

78. Schrier-Uijl, A.P. et al. Agricultural peatlands: towards a greenhouse gas sink-a synthesis of a Dutch landscape study. Biogeosciences, 11, 4559-4576 (2014).

79. Hadden, D. \& Grelle, A. The impact of cultivation on $\mathrm{CO}_{2}$ and $\mathrm{CH}_{4}$ fluxes over organic soils in Sweden. Agric. Forest Meteorol. 243, 1-8 (2017).

80. Valdés-Barrera, A., et al. Effects of disturbance on the carbon dioxide balance of an anthropogenic peatland in northern Patagonia. Wetlands Ecol. Manage. 27, 635-650 (2019).

81. Langeveld, C.A. et al. Emissions of $\mathrm{CO}_{2}, \mathrm{CH}_{4}$ and $\mathrm{N}_{2} \mathrm{O}$ from pasture on drained peat soils in the Netherlands. Eur. J. Agron. 7, 35-42 (1997).

82. Hatala, J.A. et al. Greenhouse gas $\left(\mathrm{CO}_{2}, \mathrm{CH}_{4}, \mathrm{H}_{2} \mathrm{O}\right)$ fluxes from drained and flooded agricultural peatlands in the Sacramento-San Joaquin Delta. Agric. Ecosys. Environ. 150, 1-18 (2012).

83. Knox, S.H. et al. Agricultural peatland restoration: effects of land-use change on greenhouse gas $\left(\mathrm{CO}_{2}\right.$ and $\left.\mathrm{CH}_{4}\right)$ fluxes in the Sacramento-San Joaquin Delta. Global Change Biol. 21, 750-765 (2015).

84. Campbell, D.I., Wall, A.M., Nieveen, J.P. \& Schipper, L.A. Variations in $\mathrm{CO}_{2}$ exchange for dairy farms with year-round rotational grazing on drained peatlands. Agric. Ecosys. Environ. 202, 6878 (2015).

85. Fleischer, E., Khashimov, I., Hölzel, N., Klemm, O. Carbon exchange fluxes over peatlands in Western Siberia: Possible feedback between land-use change and climate change. Sci. Total Environ. 545-546, 424-433 (2016).

86. Lohila, A., Aurela, M., Tuovinen, J.P. \& Laurila, T. Annual $\mathrm{CO}_{2}$ exchange of a peat field growing spring barley or perennial forage grass. J. Geophys. Res.: Atmos. 109, D18116 (2004).

87. Regina, K., Pihlatie, M., Esala, M. \& Alakukku, L. Methane fluxes on boreal arable soils. Agric. Ecosys. Environ. 119, 346-352 (2007).

88. Rankin, T., Strachan, I.B. \& Strack, M. Carbon dioxide and methane exchange at a postextraction, unrestored peatland. Ecol. Engineer. 122, 241-251 (2018).

89. Hendriks, D.M.D., Van Huissteden, J., Dolman, A.J. \& Van der Molen, M.K., 2007. The full greenhouse gas balance of an abandoned peat meadow. Biogeosciences 4, 411-424 (2007).

90. Shurpali, N.J. et al. Cultivation of a perennial grass for bioenergy on a boreal organic soil-carbon sink or source? Global Change Biol. Bioenergy, 1, 35-50 (2009)

91. Gong, J. et al. 2014. Climatic sensitivity of the $\mathrm{CO}_{2}$ flux in a cutaway boreal peatland cultivated with a perennial bioenergy crop (Phalaris arundinaceae, L.): Beyond diplotelmic modeling. Agric. Forest. Meteorol. 198, 232-249 (2014).

92. Nugent, K.A., Strachan, I.B., Strack, M., Roulet, N.T. \& Rochefort, L. Multi-year net ecosystem carbon balance of a restored peatland reveals a return to carbon sink. Global Change Biol. 24, 5751-5768 (2018).

93. Nieveen, J.P., Jacobs, C.M. \& Jacobs, A.F. Diurnal and seasonal variation of carbon dioxide exchange from a former true raised bog. Global Change Biol. 4, 823-833 (1998).

94. Rigney, C. et al. Greenhouse gas emissions from two rewetted peatlands previously managed for forestry. Mires \& Peat 21, 24 (2018).

95. Kiew, F. et al. $\mathrm{CO}_{2}$ balance of a secondary tropical peat swamp forest in Sarawak, Malaysia. Agric. Forest Meteorol. 248, 494-501 (2018).

96. Hirano, T. et al. Effects of disturbances on the carbon balance of tropical peat swamp forests. Global Change Biol. 18, 3410-3422 (2012).

97. Brown, E.L. Greenhouse gas flux response to restoration management in UK lowland peatlands. PhD thesis, School of Environment, Natural Resources and Geography, Bangor University, UK. 
98. Denmead, O.T. (2008) Approaches to measuring fluxes of methane and nitrous oxide between landscapes and the atmosphere. Plant Soil 309, 5-24.

99. Baird, A.J., Holden, J., Chapman, P. A literature review of evidence on emissions of methane in peatlands. Defra project SP0574, University of Leeds, Leeds (2009).

100. Green, S.M. \& Baird, A.J. Using 'snapshot' measurements of $\mathrm{CH}_{4}$ fluxes from an ombrotrophic peatland to estimate annual budgets: interpolation versus modelling. Mires and Peat 19, 9 (2017).

101. Green, S.M., \& Baird, A.J. A mesocosm study of the role of the sedge Eriophorum angustifolium in the efflux of methane - including that due to episodic ebullition - from peatlands. Plant and Soil 351, 207-218 (2012).

102. Stanley, K.M., Heppell, C.M., Belyea, L.R., Baird, A.J. \& Field, R.H. The importance of $\mathrm{CH}_{4}$ ebullition in floodplain fens. Journal of Geophysical Research: Biogeosciences 124, 1750-1763 (2019).

103. Yamulki, S., Peace, A. \& Morison, J.I.L. Soil $\mathrm{CO}_{2}, \mathrm{CH}_{4}$ and $\mathrm{N}_{2} \mathrm{O}$ fluxes from an afforested lowland raised peatbog in Scotland: implications for drainage and restoration. Biogeosciences 10, 10511065 (2013).

104. Gauci, V., Dise, N. \& Fowler, D. Controls on suppression of methane flux from a peat bog subjected to simulated acid rain sulfate deposition. Global Biogeochem. Cycl. 16, 1004 (2002).

105. Laine, A., Wilson, D., Kiely, G. \& Byrne, K.A. Methane flux dynamics in an Irish lowland blanket bog. Plant Soil 299, 181-193 (2007).

106. Drewer, J. et al. Comparison of greenhouse gas fluxes and nitrogen budgets from an ombotrophic bog in Scotland and a minerotrophic sedge fen in Finland. Eur. J. Soil Sci. 61, 640650 (2010).

107. Renou-Wilson, F., Müller, C., Moser, G. \& Wilson, D. To graze or not to graze? Four years greenhouse gas balances and vegetation composition from a drained and a rewetted organic soil under grassland. Agric. Ecosys. Environ. 222, 156-170 (2016).

108. Wilson, D. et al. Rewetting of Cutaway Peatlands: Are We Re-Creating Hot Spots of Methane Emissions? Restor. Ecol. 17, 796-806 (2009).

109. Wilson, D. et al. Multiyear greenhouse gas balances at a rewetted temperate peatland. Global Change Biol. 22, 4080-4095 (2016)

110. Levy, P.E. et al. Methane emissions from soils: synthesis and analysis of a large UK data set. Global Change Biol. 18, 1657-69 (2012) 